\title{
W KRAINIE ULRO. RELIGIJNE WYOBRAŻENIA O KOSMOSIE I CZŁOWIEKU WOBEC NAUKOWEGO OBRAZU ŚWIATA
}

\author{
Jonathan Scovil \\ Uniwersytet Warszawski
}

Nowożytna nauka wprowadziła do potocznej refleksji pojęcia, które w znaczący sposób zmieniły nasz obraz świata i wytyczyły ludzkiej wyobraźni nowe granice. Czy Jezus Chrystus naprawdę zmartwychwstał? To pytanie przez wieki zadawały sobie dziesiątki ludzi, od niego zależała ich wiara bądź niewiara, spełnienie najgłębszych nadziei, sens przypisywany życiu i światu. Odpowiedź, tak dawniej, jak i współcześnie, zależy nie tylko od tego, czy potrafimy zaufać słowom Pisma Świętego, ale także od naszej zdolności do wyobrażenia sobie zmartwychwstania jako empirycznego faktu. Czy jednak po nowożytnej rewolucji naukowej nie stało się to trudniejsze? Czy nie jest nam trudniej wierzyć ewangelistom, odkąd wiemy, jak zawodne potrafią być ludzkie zmysły? Czy nie jest nam trudniej wierzyć w cudowne uzdrowienia, odkąd słyszeliśmy o efekcie placebo?

Trudno w sposób ścisły badać siłę ludzkiej wiary, stąd właściwsza formą omawiania tych zagadnień wydaje się raczej filozoficzny esej, zarysowujący zasadniczą naturę problemu, niż raport z badań sondażowych. Wśród polskich autorów tę pierwszą ścieżkę obrał przede wszystkim Czesław Miłosz w wydanej w 1982 roku Ziemi Ulro. Zamiast rozpatrywać napięcia między chrześcijańską i naukową wizją świata w kategoriach czysto intelektualnych, Miłosz kładł nacisk na sferę wyobrażeń zbiorowych, w której - jego zdaniem - dochodzi do ich najbardziej znaczącego starcia. Mowa tu więc nie tyle o zastapieniu „teorii” o religijnych korzeniach teo- 
riami naukowymi (np. geocentrycznej wizji naszego układu słonecznego kopernikańską teorią heliocentryczna), ile o bardziej zasadniczej zmianie światopoglądowej w szerokim tego słowa znaczeniu, a zatem o przemianie sposobu, w jaki myślimy o całej otaczającej nas rzeczywistości materialnej.

Można argumentować, że konflikt między religią chrześcijańską a nauką to sztuczny problem lub że jeśli kiedyś istniał, to dawno już nie jest aktualny, zarówno za sprawą przemian w nauczaniu Kościoła, jak i ewolucji samej nauki. Można też dowodzić, że prestiż oraz wpływ nauki na masowa wyobraźnię obecnie się zmniejszył, wskazując choćby na silne ruchy kontestujące ustalenia naukowców, takie jak ruch antyszczepionkowców czy „płaskoziemców”. Należy jednak podkreślić, że wszystkie te przemiany oddziałuja na postawiony przez Miłosza problem dominacji tzw. „naukowego światopoglądu” (1982: 181) jedynie w ograniczonym stopniu. „Treść” tego światopoglądu jest bowiem płynna (choćby wizja globalnego ocieplenia jeszcze niedawno nie była w nim obecna), ale jego ramy - granice, które narzuca naszej wyobraźni - sa znacznie bardziej stałe i nie ulegają tak łatwo zmianom. Wykroczenie poza te granice, choćby poprzez wyobrażenie sobie zmartwychwstania w najzupełniej dosłownym sensie, jest równie utrudnione dziś, jak było w czasach, w których Miłosz pisał swój esej. Jest to swego rodzaju „,herezja” wobec „,naukowego światopoglądu”, tak jak herezją w tradycyjnym sensie pozostaje traktowanie zmartwychwstania Chrystusa jedynie jako metafory. Gdzie można dziś upatrywać rozwiązania tego zarysowanego w Ziemi Ulro i wciąż aktualnego problemu?

\section{/// Światopogląd naukowy}

$\mathrm{Na}$ wstępie należy wyjaśnić, czym właściwie charakteryzuje się „naukowy światopogląd”, o którym pisał Miłosz. Stojące za nim milczące założenia przypominają te, które już w XIX wieku formułowali tzw. scjentyści, zafascynowani gwałtownym rozwojem nauk przyrodniczych. Czym jest scjentyzm, wyjaśnia z kolei zwięzła definicja Leszka Kołakowskiego: „,...] nie będąc bynajmniej logicznym wnioskiem, dającym się wywieść z korpusu wiedzy naukowej, jest ideologia głosząca, że wartość poznawczą określa właściwe zastosowanie metod naukowych" (1988: 142). Zbliżony do scjentyzmu w swojej ufności wobec naukowej metody, ,naukowy światopogląd” jest od niego mniej spójny, ale za to łatwiej przyswajalny dla osób niezajmujących się zawodowo nauka, a żyjących na co dzień w coraz silniej stechnicyzowanym otoczeniu. Istotne jest tutaj to, że „światopogląd naukowy” poniekąd nam się narzuca, przyjmujemy go w mniejszym lub większym

\section{/ 134 STANRZECZY 1[18]/2020}


stopniu nieświadomie, biernie. Lecąc na wakacje samolotem, poruszanym nieznanymi nam, ale ujarzmionymi przez naukę siłami, jesteśmy niejako zmuszeni uznać jej prawa za obowiązujące.

Na typ idealny „naukowego światopoglądu” wydają się składać dwa kluczowe elementy: po pierwsze, ufność w możliwości wyjaśniające nowoczesnej nauki (charakterystyczne, że nawet ruchy podważające ustalenia nauki głównego nurtu zwykle powołują się na ustalenia „swoich” naukowców i ekspertów). „Naukowy światopogląd” nie wymaga od nas wyłącznie - a nawet nie głównie - przyjęcia pewnego zestawu prawd, ale raczej zbudowania w sobie owej ufności wobec naukowego poznania. Pisał o tym Max Weber:

Wzrastająca intelektualizacja i racjonalizacja nie oznacza [...] wzrostu powszechnej wiedzy o warunkach życiowych, którym podlegamy. Oznacza ona coś innego: wiedzę o tym, albo wiarę w to, że gdyby tylko człowiek tego chciał, to mógłby w każdej chwili przekonać się, że nie ma żadnych tajemniczych, nieobliczalnych mocy, które by w naszym życiu odgrywały jakąś rolę, ale wszystkie rzeczy można - w zasadzie - op a now a ć przez k a lk ula cję. Oznacza to jednak odczarowanie świata (Weber 1998: 122).

Co Weber ma na myśli, gdy pisze o „odczarowaniu świata”? Rozumie przez to m.in. postępująca, wykraczającą daleko poza mury uniwersytetów i laboratoriów, powszechną utratę zaufania do irracjonalnych wyjaśnień obserwowanych przez nas zjawisk fizycznych, społecznych itd. Decydujące jest tutaj odrzucenie możliwości występowania fenomenów wyłamujących się z uniwersalnych praw nauki. August Comte, jeden z czołowych XIX-wiecznych scjentystów, nazywał tę zasadę ,powszechnym dogmatem o niezmienności praw przyrody" (Comte 2006: 12). Ścisłe przestrzeganie tego założenia jest warunkiem sine qua non procedury naukowego przewidywania. Nietrudno przy tym zauważyć, że Comte’owski „dogmat” kłóci się z wieloma dogmatami chrześcijańskimi, np. o Maryi zawsze Dziewicy czy o Zmartwychwstaniu Jezusa.

Powyższe stwierdzenia kierują nas w naturalny sposób ku drugiemu elementowi tworzącemu typ idealny „naukowego światopoglądu”: polega on na przyjęciu kryterium prawdy, wywiedzionego z nauk przyrodniczych jako jedynego dopuszczalnego kryterium prawdy w ogóle. Uznaje ono za rzeczywiste jedynie to, czego istnienia można dowieść przy pomocy danych, uzyskanych przez naszą percepcję zmysłową (wspomaganą ewentu- 
alnie odpowiednimi instrumentami, takimi jak teleskop czy mikroskop), lub za pomocą eksperymentu. Prawda chrześcijańskiego Objawienia może funkcjonować w jej ramach co najwyżej jako subiektywna narracja, zależna od indywidualnego wyboru wierzącego.

Warto zresztą zauważyć, że kryterium prawdy, wywiedzione z nauk przyrodniczych, eliminuje również kategorię prawdy absolutnej. Choć zasady nauki roszcza sobie prawa do uniwersalnego statusu, nawet one sa zawsze do pewnego stopnia względne. Włączone w proces postępu naukowego, pozostaja jedynie krokiem ku pełnej prawdzie, do jakiej dąży naukowe poznanie (co do tego, czy pełnia naukowej prawdy, a zatem tzw. „teoria wszystkiego”, jest w ogóle osiagalna, naukowcy mają wciąż wątpliwości; Hawking 1990: 144-158). Historia nauki pokazuje dobitnie, że tylko nielicznym spośród nawet najbardziej wpływowych teorii i paradygmatów pisane było zachować aktualność aż do naszych czasów. Pisał o tym Edmund Husserl:

Idea prawdy w tym znaczeniu, o które idzie w nauce, różni się [...] od prawdy życia przednaukowego. Chce ona być prawdą bezwarunkową. Zawarta w tym jest pewna nieskończoność, która każdemu faktycznemu potwierdzeniu i każdej faktycznej prawdzie nadaje charakter czegoś relatywnego, przybliżenia jedynie, odniesionego właśnie do owego nieskończonego horyzontu, w którym prawda sama w sobie jest, by tak rzec, odległym punktem (1993: 22).

Ekspansja „naukowego światopoglądu” w obrębie cywilizacji europejskiej wiąże się ściśle z napięciem, jakie narastało przez setki lat pomiędzy twierdzeniami rozwijającej się nauki (głównie nauk ścisłych, choć nie tylko) a dogmatami religii chrześcijańskiej. Proces rozchodzenia się prawd nauki i wiary przebiegał co najmniej dwutorowo. $Z$ jednej strony rozwijała się stopniowo empiryczna metoda poznawcza wraz z właściwym jej kryterium prawdy, o którym była mowa wcześniej. Z drugiej jednak strony chwiejnym przymierzem nauki i wiary wstrząsały także wielkie naukowe odkrycia, stające nieraz w sprzeczności wobec nauczania Kościoła i jednocześnie zdolne oddziałać na zbiorową wyobraźnię.

Pierwszy z wymienionych procesów rozpoczął się bardzo wcześnie, a późniejsze rewolucje naukowe można traktować poniekąd jako jego konsekwencje. Prześledźmy więc najpierw drogę rozwoju metody epistemologicznej, która wyrugowała wyobrażenia religijne z dziedziny obiek-

\section{/ 136 STANRZECZY 1[18]/2020}


tywnej prawdy naukowej. Podobną próbę - choć w znacznie szerszym zakresie - podją Leszek Kołakowski na kartach swojej książki pt. Filozofia pozytywistyczna (1966). Wspominany wcześniej nurt scjentyzmu, z którym „światopogląd naukowy” dzieli swoje najbardziej charakterystyczne cechy, ukształtował się bowiem właśnie na łonie tej filozofii.

W poszukiwaniu zalążków przyszłej metody pozytywistycznej Kołakowski cofa się aż do starożytności. Już w pismach stoików, sceptyków i atomistów przewijaja się pierwsze postulaty antymetafizyczne, które z czasem miały zostać wyraźniej sformułowane, by odnaleźć oparcie w precyzyjnej, zawężonej definicji prawdy. Na kolejne tropy natrafiamy w późnym średniowieczu - a zatem w czasach podporządkowania nauki religii - m.in. w pracach Rogera Bacona, skłaniającego się ku empiryzmowi (choć poza doświadczeniami zmysłowymi uznawał on również doświadczenia nadzmysłowe, np. mistyczne; Tatarkiewicz 2003: 269) i podkreślającego fundamentalną wagę eksperymentu w ludzkim poznaniu. U Wilhelma Ockhama, twórcy słynnej „brzytwy ockhamowskiej”, odnaleźć można stanowcze postulaty empirycystyczne oraz nominalistyczne, a także ostre rozróżnienie przedmiotu zainteresowań nauki i religii. Idee obu średniowiecznych myślicieli rozwijali ich następcy (Kołakowski 1966: 19-26).

Konflikt między niektórymi roszczeniami nauki i religii miał się zaognić w epoce nowożytnej. Na tym etapie rozwoju empirycznej metody kluczową rolę odegrał Galileusz. Jako pierwszy przedstawił w przejrzystej formie fenomenalistyczny program poznania, zakładający brak rzeczywistej różnicy pomiędzy „zjawiskiem” a jego „istotą” i nakazujący przykładać w nauce wagę jedynie do tego pierwszego (więc np. buchający płomień nie porusza się już w górę dlatego, że to, co ogniste, ma z natury swoje miejsce w górze, tak jak rozumował Arystoteles; 1968). Prowadziło to do odrzucenia wszelkich metafizycznych wyjaśnień w badaniu zjawisk przyrodniczych, pojmowanych odtąd przyczynowo, mechanistycznie. Podobne założenia upowszechniał Pierre Gassendi, z takim samym nastawieniem do swoich badań podchodzili także Leibniz czy Locke (Kołakowski 1966: 32-34).

W tamtych czasach dominująca postawą w kręgach uczonych nie był wcale deizm ani ateizm (większość czołowych myślicieli tego okresu była wierząca, a wielu badaczy należało do duchowieństwa), ale akceptacja dla ścisłego rozdzielenia przedmiotu poznania religii i nauki (tamże: 29-30). Jednak w rzeczywistości konflikt już trwał. Zdawał sobie z tego sprawę Kościół katolicki, o czym świadczyć mogą choćby słynne a niesławne procesy inkwizycyjne Galileusza i Giordana Bruna. Rewolucyjne przemiany w ów- 
czesnej nauce nie mogły pozostać całkowicie neutralne w stosunku do prawd religijnych. Zasada fenomenalizmu, potraktowana konsekwentnie, musiała stać się czymś więcej niż tylko postulatem badawczym. Rozdzielenie obszarów wyjaśnianych przez naukę i wiarę prowadziło wierzących uczonych do mniej lub bardziej arbitralnych podziałów Pisma Świętego na fragmenty, które należy pojmować dosłownie, i te, które pozostaja jedynie metaforami - alegorycznie należało rozumieć oczywiście wszystko to, co stało w sprzeczności z prawami nauk przyrodniczych (podobna taktykę przyjęło zresztą wielu nowoczesnych teologów; Strauss 2006: 141-180). Kołakowski pisał: „,[...] od XVII wieku było właśnie tak - racjonaliści nie silą się już na argumenty, że takie czy inne cudowne wydarzenie nie ma oparcia w źródłach historycznych, uznając, że takie wydarzenia po prostu «nie mogły zaistnieć, bo naruszają prawa natury»" (2014: 60).

Wiara w uniwersalność praw nauki, przyjmowana przez ówczesnych badaczy za swego rodzaju aksjomat, już niedługo przemieniła się w sztywne ramy, poza które nieliczni potrafili jeszcze sięgnąć wyobraźnią. Comte'owski „powszechny dogmat o niezmienności praw przyrody” jeszcze nie został ogłoszony, a już kształtował największe umysły epoki. W czasach oświecenia ufność w moc ludzkiego rozumu, a co za tym idzie - wytwarzanej przez niego nauki - jedynie przybrała na sile. Nie zachwiały nia prace Davida Hume’a, jedynego filozofa tamtych czasów, który był w stanie doprowadzić empiryzm oraz poznawczy sceptycyzm do ich ostatecznych konsekwencji, czyli - mówiąc najprościej - wymogu nieufności wobec wszelkich praw i wiedzy, dostępnych naszym umysłom (Kołakowski 1966: 51). Na tym etapie konflikt pomiędzy prawdami nauki i prawdami wiary staje się coraz bardziej jawny, a wśród intelektualnych elit upowszechnia się sceptyczny stosunek do religii. Wreszcie w XIX wieku pojawia się właściwa filozofia pozytywistyczna, a razem z nią scjentyzm, podwaliny nowoczesnego „światopoglądu naukowego”.

Zatrzymując się w opisie ewolucji metody naukowej na tym etapie, nie chcę oczywiście sugerować, że tu się ona zakończyła. Wydaje się jednak, że potoczny „naukowy światopogląd” przesiąknął w głównej mierze ideami tego właśnie okresu. Wtedy omawiany konflikt przeniknął do ogólnospołecznej świadomości, a nauka osiągnęła apogeum swojej mocy oddziaływania na masową wyobraźnię. W XX wieku jej prestiż mógł co prawda rosnąć, ale bezpośredni wpływ poszczególnych teorii naukowych na zbiorowe wyobrażenia o otaczającym nas świecie malał. Przyczyny tego stanu rzeczy tłumaczą słowa Michała Hellera: 
Wiek XX rozpoczął się od wielkiej rewolucji w podstawach fizyki i całe stulecie upływało pod znakiem następstw (a może dalszego ciagu) tej rewolucji. Teorie naukowe stawały się coraz bardziej abstrakcyjne, a tym samym coraz bardziej odległe od przetwórczych możliwości naszej wyobraźni. Fakt ten powoduje, iż naukowe teorie $\mathrm{w}$ znacznie mniejszym stopniu niż to miało miejsce w ciągu ostatnich trzystu lat kształtują obraz świata funkcjonujący we współczesnej kulturze (Heller, Krajewski 2014: 165).

Jak wspomniałem wyżej, za rozejściem się prawd wiary i nauki stały również niektóre z odkryć naukowych, które w szczególny sposób burzyły obraz wszechświata zawarty w nauczaniu Kościoła. Do zdarzeń tego rodzaju zaliczyć należy z pewnością upowszechnienie teorii heliocentrycznej Kopernika (nieprzeczącej co prawda słowom zawartym w Biblii, ale obalającej wizję podtrzymywaną przez Kościół) i teorii ewolucji Darwina (kłócącej się z obrazem zawartym w Starym Testamencie). O ich wadze decydowały nie ich praktyczne konsekwencje, ale moc oddziaływania na wyobraźnię zwykłych ludzi.

$\mathrm{Na}$ tej samej zasadzie działały najbardziej widowiskowe dokonania naukowców. Co mógł zmienić w życiu przeciętnego człowieka lot radzieckiego astronauty w kosmos czy lądowanie Amerykanów na Księżycu? W praktyce raczej niewiele. Podobne wyczyny oddziaływały jednak w zupełnie innej sferze. Neil Armstrong wykonał wielki skok dla ludzkości, a gdy Jurij Gagarin mówił, że w kosmosie nie widział Boga, stawiał właśnie ostatni krok na drodze do obalenia odwiecznych wyobrażeń zaświatów skrytych pośród chmur.

\section{/// Przemiana wyobrażeń o kosmosie}

Jaki wpływ wywarła ekspansja „naukowego światopoglądu” na zbiorową wyobraźnię? Miłosz w Ziemi Ulro koncentruje się na oddziaływaniu spopularyzowanych ustaleń nauk ścisłych na dziedzinę religijnych wyobrażeń chrześcijan, zmiana jest jednak szersza. Podstawowe wyobrażenia członków zachodniej cywilizacji na temat otaczającej nas rzeczywistości były przez wieki kształtowane przez religię i dlatego przemiana, o której tu mowa, dotknęła całych społeczeństw. By ją wyjaśnić, warto posłużyć się ukutym przez Charlesa Taylora pojęciem „kosmicznego imaginarium” (cosmic imaginary). Kanadyjski filozof określał tym terminem zespół wyobrażeń o otaczającym nas wszechświecie (kosmosie) i miejscu, jakie sami 
w nim zajmujemy. Takie imaginarium zakreśla ramy, w jakich myślimy o materialnej rzeczywistości. Jego przejawy można dostrzec w tym, jak przedstawiany jest świat np. w naszej nauce lub w doktrynach religijnych (Taylor 2007: 323).

Taylor wskazuje na znacząca przemianę naszego „kosmicznego imaginarium", postępująca w ciągu ostatnich kilkuset lat. Podstawowa zmiana zasadza się na przejściu od wyobrażenia otaczającej nas rzeczywistości jako „kosmosu” do wyobrażenia jej jako „wszechświata”. Pierwszy termin opisuje dawne, przednaukowe imaginarium, choć Taylor nie wyjaśnia precyzyjnie, co rozumie pod tym pojęciem. Wydaje się jednak, że odpowiada ono mniej więcej ujęciu Mircea Eliadego, prezentowanemu w jego analizie wierzeń społeczeństw tradycyjnych: „kosmos” stanowi tu opozycję do mitycznego „chaosu”, jako uporządkowany i uświęcony „nasz świat”, wydzielony z bezładnej i groźnej przestrzeni, która go otacza (Eliade 2008: 27). Tymczasem wyobrażenie rzeczywistości jako „wszechświata” czyni przestrzeń jednorodna (nie ma już „naszego” i „obcego” świata, jest tylko nieokreślona, fizyczna przestrzeń wokół nas), desakralizuje ją i jednocześnie „odczarowuje”. Taylor pisał:

Od kosmosu do wszechświata: sposób, w jaki świat jest wyobrażany, uległ zmianie. [...] Ta zmiana, która dokonywała się przez ostatnie pół tysiąclecia w obrębie naszej cywilizacji, była olbrzymia. Przenosimy się z zaczarowanego świata, zamieszkałego przez duchy i magiczne siły, do świata odczarowanego; jednak być może ważniejsze jest to, że przenieśliśmy się ze świata statycznego i posiadającego określone granice, do świata, który jest przepastny, wydaje się nieskończony, a zarazem znajduje się w toku ewolucji rozciagniętej na eony [tłum. własne - J.S.] (2007: 323).

Filozof łączy ten proces z rozwojem nowożytnej nauki, ale wielokrotnie podkreśla, że popularne wyjaśnienia przemiany, takie jak „Darwin obalił Biblię" (tamże: 4), uważa za dalece niesatysfakcjonujące. Poza fałszywością samego stwierdzenia, Taylorowi nie odpowiada również czysto teoretyczne ujęcie problemu:

Moje wątpliwości wynikają stąd, że takie wyjaśnienie ukazuje nam zastąienie jednej teorii druga; tymczasem mnie interesuje to, jak nasze odbieranie rzeczywistości, nasze kosmiczne imaginarium, innymi słowy, całe nasze rozumienie i odczuwanie świata, uległo 
zmianie. To są zupełnie różne zjawiska. Jakaś teoretyczna zmiana mogłaby pozostawić nasze imaginarium nietknięte; tak dzieje się przecież w przypadku większości bardziej wyrafinowanych i ezoterycznych osiagnięć współczesnej nauki [tłum. własne - J.S.] (tamże: 325).

Na czym więc polegał wyobrażeniowy zwrot, o którym pisze Taylor? Aby to zrozumieć, musimy przyjrzeć się najbardziej fundamentalnym różnicom pomiędzy nowoczesnym imaginarium kosmicznym, przesiąkniętym „naukowym światopoglądem”, a imaginarium przednaukowym, poprzedzającym Weberowskie „odczarowanie” (w tym miejscu warto podkreślić, że piszę wyłącznie o imaginariach panujących w obrębie zachodniej cywilizacji chrześcijańskiej). Głównymi obszarami rozbieżności wydają się: A. akceptacja dla nadprzyrodzonych wyjaśnień zjawisk fizycznych, B. pojęcie „sensu” świata, C. wyobrażenie świata w czasie i przestrzeni.

A. O pierwszym z wymienionych punktów wspominałem już wcześniej, przy okazji rozważań nad charakterystycznymi cechami „naukowego światopoglądu". Podczas gdy dawne imaginarium kosmiczne wspierało się na wierze $\mathrm{w}$ tajemnicze moce $\mathrm{i}$ byty nadprzyrodzone, mogące oddziaływać bezpośrednio na bieg rzeczy i wymykające się ludzkiemu rozumowi, w nowoczesnym imaginarium nie ma miejsca dla podobnych uzasadnień zjawisk fizycznych. Charles Taylor podkreśla, że do „odczarowania” kosmosu przyczyniła się w przeważającej mierze mechanistyczna koncepcja natury, która upowszechniła się wśród XVII-wiecznych uczonych, takich jak Boyle czy Newton (tamże: 329). Świat-maszyna został ciasno opleciony sieciami związków przyczynowo-skutkowych oraz żelaznymi prawami nauki, których nie mogli już podważać ani ludzie, ani tym bardziej bogowie. Choć powstanie mechaniki kwantowej obaliło mechanistyczna teorię determinizmu przyrody, wpływ tej wizji na zbiorową wyobraźnię pozostaje wciąż znaczący. Pisał o tym Michał Heller: „Mechanistyczny obraz świata do tego stopnia zrósł się z ogólną kulturą, że - mimo iż z początkiem XX stulecia całkowicie utracił oparcie w nauce - do dziś jest obecny w przekonaniach wielu ludzi, jak i w wielu wytworach kultury" (Heller, Krajewski 2014: 165).

B. Kolejnym podstawowym punktem spornym pomiędzy dawnym i nowoczesnym imaginarium kosmicznym jest „sensowność” otaczającego nas świata. Mówiąc najprościej, mowa tu o odpowiedziach udzielanych na pytanie: „dlaczego?”. Dlaczego jesteśmy na tym świecie? Dlaczego powstał wszechświat? Wreszcie można zapytać za Leibnizem: Dlaczego istnieje ra- 
czej coś niż nic? Otóż jedną z najbardziej podstawowych różnic między omawianymi tu imaginariami jest to, że dawne zawierało w sobie odpowiedzi na te pytania, a nowoczesne nie. W przednaukowych wyobrażeniach kształtowanych przez religię chrześcijańską świat miał „sens” głównie dlatego, że był stworzony przez Boga. To założenie dawało istnieniu wszechrzeczy przyczynę, ale przede wszystkim cel.

Celowość wszechświata splatała się z antropocentryzmem - Ziemia jawiła się jako stworzona specjalnie dla ludzi po to, by ,uczynili ja sobie poddana” (Rdz 1,28) i korzystali z przeznaczonych im bogactw natury. Sens istnienia otaczających człowieka rzeczy tłumaczyło jego własne istnienie. Wraz z „odczarowaniem” świat poniekąd stracił uzasadnienie, a kolejne naukowe odkrycia kazały ludziom rezygnować z przypisywania sobie dużej roli w tym przepastnym wszechświecie pozbawionym raison d'être. We współczesnej kosmologii naszemu istnieniu przypisuje się większą wage niż w XIX wieku, czego dowodem może być choćby popularność w kręgach naukowych tzw. argumentu antropicznego, którego logika wyraża się w stwierdzeniu: „świat jest, jaki jest, ponieważ my w nim żyjemy” (Heller, Krajewski 2014: 177). Zauważmy jednak, że również ta zasada wymija pytanie o „sens” rzeczy i stwierdza jedynie fakt, że wszechświat musiał być dokładnie taki, a nie inny, by możliwe było na nim powstanie tak złożonej formy życia. „Sens” jest bowiem kategorią z gruntu nienaukową i dlatego nie występuje również w nowoczesnym kosmicznym imaginarium. Max Weber pisal:

[...] w ścisłych naukach przyrodniczych, gdzie dzieła Boga były fizycznie obecne, spodziewano się odnaleźć ślady zamiarów, jakie żywi wobec świata. A dzisiaj? Kto - poza paru profesorami nauk przyrodniczych, którzy sa jak duże dzieci - wierzy jeszcze dzisiaj, że wiedza uzyskana w astronomii czy też w biologii, fizyce czy chemii może powiedzieć nam cokolwiek o sensie świata? (1998: 125)

Szukanie sensu świata w strukturze wszechświata okazuje się więc niczym więcej, jak próbą przeniesienia potrzeby ładu i celowości zakorzenionej w naszych umysłach na rzeczywistość całkowicie pozaludzką, obojętną wobec naszych wartości i pragnień. Obraz wszechświata, który zawdzięczamy nowoczesnej nauce, został zresztą tak dalece oczyszczony z wszelkich elementów antropomorficznych, że niemal całkowicie wykroczył poza ramy ludzkiej wyobraźni. Znamienne są słowa Erwina Schrödingera, jednego z twórców mechaniki kwantowej, którego zdaniem wszechświat,

\section{/ 142 STANRZECZY 1[18]/2020}


jakim zajmowała się nauka w XX wieku, jest nie tylko ,[...] praktycznie niedostępny, ale wręcz nie do pomyślenia [...] jakkolwiek go pomyślimy, jest błędny; może nie tak całkiem bezsensowny jak «trójkątne koło», ale o wiele bardziej niż «skrzydlaty lew»" (Schrödinger 1952, cyt. za: Arendt 2010: 324).

C. Ostatnim ważnym obszarem rozbieżności między imaginariami wydaje się być sposób, w jaki świat jest wyobrażany w czasie i przestrzeni. Zmiana, która nastapiła w tej dziedzinie, była kolosalna. Przez całe stulecia mieszkańcy chrześcijańskiej Europy sądzili, że tkwią w samym środku kosmosu, otoczeni przez krążące wokół nich planety, gwiazdy stałe oraz ograniczoną ilość kosmicznych sfer, za którymi znajduje się siedziba Boga i aniołów. Rozmiary średniowiecznego świata mogły być może przytłaczać zwykłych ludzi, ale nie przekraczały zasięgu ich wyobraźni. Inaczej jest ze wszechświatem nowoczesnego imaginarium - niemal nieskończona przestrzeń rozpościerająca się wokół nas (pamiętajmy, że rozrosła się ona zarówno w skali makro, jak i mikro) jest właściwie nie do objęcia ludzkim umysłem.

Zdaniem Taylora jeszcze większy wpływ na wyobraźnię zbiorową wywarła przemiana w rozumieniu czasu. Historia wszechświata niespodziewanie wydłużyła się od 5000-6000 lat do milionów stuleci (a przejściowo wręcz do nieskończoności). Wraz z przyjęciem teorii ewolucji ludzie zmuszeni byli uznać, że otaczająca ich rzeczywistość nie jest niczym stałym, ale podlega ciagłym zmianom. Musieli także przyjąć, że świat jest bez porównania starszy od nich. Wyłączenie człowieka z wczesnych dziejów kosmosu godziło oczywiście w jego dumę, ale co jeszcze ważniejsze, stawiało kolejną tamę dla jego wyobraźni. Natrafiamy bowiem na opór, ilekroć usiłujemy wyobrazić sobie miliony lat rozwoju niezamieszkanego wszechświata, nieoglądanego żadnym okiem (Taylor 2007: 326-328). Kiedy próbujemy to zrobić, widzimy przed sobą tylko mniej lub bardziej fantastyczny obraz, nawet jeśli mamy pełną świadomość, że żadne widzenie nie byłoby wtedy możliwe. Jest to ta sama granica wyobraźni, na którą natrafiamy, mierząc się ze słynnymi paradoksami Berkeleya: Czy w lesie, w którym nikogo nie ma, padające drzewo wydaje dźwięk?

Taylor przytacza wypowiedzi wielkich uczonych, żyjących w czasach przemiany „kosmosu” we „wszechświat”. Kepler wyrażał swoje „utajone i ukryte przerażenie" nieobjęta przestrzenią Bruna, a Blaise Pascal przyznawał: „wieczna cisza tych nieskończonych przestrzeni napełnia mnie trwoga [tłum. własne - J.S.]" (Rossi 1984, cyt. za: Taylor 2007: 337). Możemy sobie wyobrazić, jak wielką grozę budziła nowa wizja wszechświata w umysłach 
pamiętających jeszcze dawny „kosmos”. Niewyobrażalność „wszechświata" opierała się na jego obcości wobec człowieka, na tym, że istniał zupełnie od nas niezależnie, a zatem nie miał „sensu” w żadnym ludzkim rozumieniu. Niepokojąco obcy musiał się wydawać również stwórca tak przepastnego, pustego uniwersum, którego olbrzymie przestrzenie nie były Ziemianom dostępne, a zatem nie były im również przeznaczone.

Warto podkreślić, że imaginaria kosmiczne i „naukowy światopogląd”, o których była tu mowa, należy traktować jak Weberowskie typy idealne. Sa to jedynie abstrakcyjne modele pewnych sposobów myślenia i odbierania rzeczywistości, których najbardziej znaczące cechy zostały celowo uwypuklone. Empirycznie nie występują one w takiej ostrości, są rozmyte i można obserwować ich rozmaite wersje (Weber 2006: 144-146). Zarówno „światopogląd naukowy”, jak i nowoczesne imaginarium kosmiczne często nie są przyjmowane przez współczesnych mieszkańców naszej cywilizacji w sposób spójny, konsekwentny czy choćby świadomy. Moje założenie było tutaj podobne do tego, które poczynił Charles Taylor, przystępując do swoich rozważań nad współczesnymi wyobrażeniami wszechświata:

Mówię tutaj o sposobie, w jaki wszechświat jest spontanicznie wyobrażany, a przez to doświadczany. Nie jest już czymś zwyczajnym natychmiastowe i bezproblemowe odbieranie wszechświata jako skonstruowanego celowo, chociaż refleksja, medytacja czy rozwój duchowy moga kogoś doprowadzić do postrzegania go w ten sposób [tłum. własne - J.S.] (Taylor 2007: 325).

Dla Taylora przemiana kosmicznego imaginarium jest przemianą ram zbiorowej wyobraźni, tworzących tło, ale i ograniczenie dla wszystkich naszych przekonań na temat otaczającej nas rzeczywistości: „,[...] to więcej niż prosta zmiana teorii. To przeobrażenie ram, w których powstaja teorie, ram, które definiuja, co jest do pomyślenia i jakie pytania maja zostać postawione [tłum. własne - J.S.]" (tamże: 349). Dostrzegamy zatem, że omawiane tu przemiany sa zarazem doniosłe i niełatwe do uchwycenia, niepoddające się nigdy w pełni precyzyjnemu ujęciu: tak jak język z trudem opisuje własne ograniczenia, tak wyobraźnia z trudem rozpoznaje swoje nowe ramy. 


\section{/// Przemiana wyobrażeń o człowieku}

Omawiane przemiany wyobrażeń o wszechświecie wpłynęły również na wyobrażenia człowieka o sobie samym. Odtwarzając porządek wywodu przyjęty powyżej, zastanówmy się najpierw nad wpływem, jaki na obraz człowieka mogło wywrzeć Weberowskie „odczarowanie świata”, odrzucenie nadprzyrodzonych wyjaśnień zjawisk fizycznych i pojawienie się nowożytnego pojęcia naukowych praw natury - nienaruszalnych, absolutnych, działających na zasadzie ślepej konieczności. Czy nasza świadomość i wolna wola nie okazałyby się również czymś nadprzyrodzonym, gdyby nie obejmowały ich prawa podobne prawom przyrody? Te same wszechogarniające zasady musiały dosięgnąć również człowieka, wnikając w niego głęboko, począwszy od jego fizjologii, aż po strukturę psychiki i schematy zachowań.

Zwłaszcza w XX wieku zasięg naszej woli zdawał się wciąż kurczyć pod naporem naukowych konieczności: popędów, bodźców, uwarunkowań, dziedzictwa genetycznego i trudnych doświadczeń dzieciństwa. Już Freudowska psychoanaliza podważała swobodę, z jaką człowiek kieruje swoim życiem, wskazując na miotające nim ukryte siły i niejako ograniczając jego prawa autorskie do własnego życia. Jeszcze dalej posuwali się amerykańscy behawioryści, sprowadzający człowieka do rangi niewiele wyższej od rangi Pawłowskiego psa. W ich założeniu zachowaniami ludzi można było sterować za pomocą odpowiedniej stymulacji, nadając tym samym bieg całemu ich życiu (i tak składającemu się głównie z reakcji na zewnętrzne bodźce, które nasza nauka albo rozpoznaje, albo będzie rozpoznawać). Znamienne są słowa twórcy tej szkoły, Johna B. Watsona: „Psychologia, jak widzi ją behawiorysta, jest w pełni obiektywna, eksperymentalna dziedzina nauk przyrodniczych" (1990: 441). Warto tu również przytoczyć jego słynna, niewiarygodnie chełpliwą deklarację:

Dajcie mi tuzin zdrowych, prawidłowo zbudowanych niemowląt i dostarczcie im to wszystko, co składa się na mój własny, szczególny świat, a zapewniam was, że wezmę na chybił trafił jedno z nich i uczynię z niego dowolnego typu specjalistę, czy to będzie lekarz, sędzia, artysta, kupiec, a nawet żebrak czy złodziej, bez względu na jego talenty, skłonności, zdolności, zadatki i rasę przodków (tamże: 163). 
Stopniowa redukcja natury ludzkiej do zestawu zawsze tych samych popędów i motywacji odnalazła uzupełnienie w naukach społecznych - w ich ujęciu człowiek stawał się drobnym trybem społecznej machiny, poruszanej statystycznymi prawami, ową „cyfrą wymienna”, o której pisał Miłosz (1982: 132). Dobry przykład tej tendencji stanowi wydane jeszcze u schyłku XIX wieku studium Émile’a Durkheima poświęcone samobójstwom. Trudno przecież o bardziej indywidualny akt niż samobójstwo, więc jeśli nawet ono pozostaje tak ściśle uwarunkowane czynnikami społecznymi, to czym jest człowiek i jego wola? Głęboki niepokój mogła wzbudzać już pierwsza tabela książki, zatytułowana: „Stałość liczby samobójstw w najważniejszych krajach europejskich (w liczbach bezwzględnych)" (Durkheim 2011: 56). Choć analizy Durkheima moga się wydać fascynujące, to sam fakt, że liczba samobójstw z roku na rok utrzymuje się w jakimś regionie na mniej więcej stałym poziomie, wystarczająco silnie oddziałuje na wyobraźnię. Jak nazwać tę siłę, która każdego roku wypychała około 200 bawarskich samobójców przez okna lub wtrącała ich ciała pod koła rozpędzonych pociagów? Trudno tu przecież mówić wyłącznie o ludzkiej woli i emocjach, trudno tu nawet mówić o pojedynczym człowieku, skoro tak jasno dostrzegamy, że działa tu coś ogólnego, społecznego, matematycznego.

O pochłanianiu tego, co jednostkowe, przez to, co społeczne, pisała Hannah Arendt. Jej zdaniem narodziny nauk społecznych umożliwił gwałtowny wzrost liczebności zachodnich społeczeństw, który dokonał się dzięki rewolucji przemysłowej - dopiero w takich warunkach siła konformizmu i tyrania większości, znane z Tocqueville’owskich analiz demokracji, mogły stać się wystarczająco potężne, by wytworzyć obowiązujące całe społeczeństwa wzorce zachowań i pragnień. Upodobniły one ludzi do siebie nawzajem $i$ to do tego stopnia, że przewidywanie ich działań stało się rzeczywiście możliwe na gruncie matematyki (Arendt 2010: 62-65).

Skoro wszystkie nasze działania, nasze odruchy, nasze uczucia, nawet nasze myśli są tak dalece zależne od zewnętrznych czynników (nawet Freudowska „podświadomość” zdaje się działać na nasze ego jakby z zewnątrz), nasuwa się dramatyczne pytanie: czy wolna wola w ogóle istnieje? Jak wiele jest nas w nas samych? Czy nie jesteśmy tylko wyjątkowo skomplikowanymi maszynami, poruszanymi przez tysiące bodźców, które nasza nauka prędzej czy później odkryje, zaklasyfikuje, zmierzy? Czesław Miłosz ujął to krótko: „Oto choroba rozdwojonej świadomości: «myślę, więc jestem», zmienia się w «myślę (rozum obiektywny myśli?), więc mnie nie ma» [...]” (1982: 74). 
Wszystko to przyczyniało się do umocnienia w nas wyobrażenia, które podsuwała nam już teoria Darwina - zaczęliśmy postrzegać samych siebie jako uwarunkowane w swoich zachowaniach zwierzęta, co prawda wysoko rozwinięte, ale w całości przynależne światu natury, a zatem światu ślepej konieczności. Hannah Arendt wskazywała na paradoksalną zależność postęp nauki, choć czyni człowieka potężniejszym, nieuchronnie prowadzi do jego upokorzenia, do obniżenia rangi, jaką sam zmuszony jest sobie przypisywać (2011: 329).

Druga istotna przemiana naszych wyobrażeń o otaczającej nas rzeczywistości - odrzucenie pojęcia „sensu” świata, jego celowości, oczyszczenie jego obrazu z elementów antropomorficznych. Ta zmiana również musiała wpłynąć na to, jakie miejsce przypisujemy sobie w porządku wszechświata. Albowiem jeśli świat nie został stworzony dla nas, jeśli nie powstał ze względu na człowieka, to znaczy, że jest on ludziom obcy, zupełnie obojętny wobec ich istnienia, cierpień i modlitw. Skoro tak, to nie możemy już postrzegać samych siebie jako części „kosmosu” w rozumieniu Eliadego, nie mamy podstaw, by czuć się z nim związani. Nie możemy też żywić przekonania, jakoby on miał się „czuć” związany z nami. O zerwaniu niepisanego paktu między ludzkością a światem, na którego łaskę jest ona wydana, pisał Czesław Miłosz:

Jeżeli po miliardach lat ewolucji człowiek pojawił się na ziemi mocą przypadkowych mutacji, jakiekolwiek przypisywanie wszechświatowi dobrych zamiarów wobec niego jest odmianą wyobrażeń religijnych. Innymi słowy, pomiędzy dziedziną wartości człowieka i niewzruszonymi prawami wszechświata brak najmniejszego związku, nie ma też podstaw do przypuszczenia, że działaja hamulce chroniące ludzkość od ostatecznych katastrof i nieszczęść (Miłosz 1982: 258).

Jeśli świat nie ma sensu, to jak może go mieć nasze życie, historia naszego gatunku, nasze osiągnięcia, postęp? Oto kolejny aspekt obrazu człowieka, jaki wyłania się spośród prawd „naukowego światopoglądu” - być może najbardziej bolesny i najtrudniejszy do przyjęcia. Diagnozy tej nowej sytuacji duchowej człowieka Miłosz szukał we współczesnej mu literaturze, wskazując na Samuela Becketta jako na najuczciwszego wyraziciela niepokojów XX wieku (jednocześnie uważając jego twórczość za niemoralną, podobną nieustannemu wytykaniu inwalidzie jego kalectwa): 
Beckett, jak zresztą cała jemu współczesna literatura zachodnia, urbi et orbi ogłosił to, co jeszcze w dziewiętnastym wieku znane było tylko nielicznym, co sarkastycznie wyrażał Nietzsche wołając do Europejczyków: „,óż to, zabiliście Boga i myślicie, że ujdzie to wam bezkarnie?". Teraz w skali masowej nastapiło uświadomienie sobie nowej sytuacji metafizycznej człowieka, którą określa dużymi literami wypisane: NIE MA. Żadnego głosu przemawiającego ze wszechświata, żadnego zła i dobra, żadnego spełnienia oczekiwań i żadnego Królestwa (tamże: 246-247).

Wreszcie ostatnia z omawianych tu przemian imaginarium, dotyczaca wyobrażenia wszechświata w czasie i przestrzeni. Człowiek i w tym przypadku został upokorzony: odebrano mu centralne umiejscowienie we wszechświecie, który w dodatku rozrósł się do takich rozmiarów, że nasze ciała, nasze miasta, nawet nasze niebo - wszystko to, co dotąd nazywaliśmy światem - wydały nam się nieskończenie małe i nieznaczące. Podobnie rzecz miała się z czasem. Czy można sobie wyobrazić, żeby życie już nie pojedynczego człowieka, ale całej ludzkości, miało jakieś fundamentalne znaczenie dla wszechświata, który jest od niej być może kilkadziesiąt tysięcy razy starszy? Oczywiście, można, ale jest to znacznie trudniejsze niż dawniej.

Wraz z zanikiem sakralnego wymiaru przestrzeni w nowoczesnym imaginarium człowiek został pozbawiony także tego, co Mircea Eliade nazywał axis mundi, symbolicznej osi świata, organizującej przestrzeń dookoła i stanowiącej stały punkt odniesienia, umożliwiający nam orientację (2008: 36). Potrzeby takiej orientacji - porządkowania otaczającej nas rzeczywistości - nie można bagatelizować, należy ona bowiem do naszych podstawowych instynktów. Miłosz stwierdza wręcz w pewnym momencie, że ,[...] człowiek jest przede wszystkim organizatorem przestrzeni [...]” (1982: 251). Żeby orientacja w przestrzeni była możliwa, niezbędny jest absolutny punkt odniesienia, coś stałego, co mogłoby się stać centrum naszego świata, czyli Eliadowskiego „kosmosu”, wydzielonego z chaosu jednorodnej, wrogiej przestrzeni. Nowe kosmiczne imaginarium, na które początkowo tak silnie oddziałały teorie Newtona, czyniło odnalezienie takiego punktu właściwie niemożliwym: „Wszechświat osiemnastego wieku: nieskończona liczba planet wirujących w nieskończonej i absolutnej przestrzeni. Łatwo to napisać, ale spróbujmy tylko to sobie wyobrazić i ustanowić w takiej nieskończoności nasz dom” (tamże: 163). 
Również czas, tracąc swój wymiar sakralny, stał się w dużej mierze jednorodny. Cykliczność obchodzonych świąt traci stopniowo dawną moc dzielenia (porządkowania) czasu na „świecki czas” i „święty czas” prapoczątku, ponownego uobecniania mitu, wydzielony ze zwykłego porządku przemijania (Eliade 2008: 20-21) (chrześcijańska Wielkanoc nie powinna być przecież tylko wspomnieniem Zmartwychwstania, ale właśnie jego ponownym przeżyciem, cofnięciem się do czasów Chrystusa). Istnieje zatem tylko jeden rodzaj czasu, mierzony mechanicznie w godzinach, dniach i latach, nieustannie obracający wszystko w niebyt i wykluczający możliwość powrotu do uświęconej przeszłości. Egzystencja pojedynczego człowieka w takim czasie wydaje się zaledwie biologicznym trwaniem, ciagłym, nieprzerwanym zmierzaniem ku śmierci, po której nie nastąpi nic.

Jeszcze jedną istotną konsekwencją przyjęcia niektórych z opisywanych tu wyobrażeń może być zatracenie ufności człowieka we własne zdolności poznawcze. Obraz wszechświata wyłaniający się z prawd współczesnej nauki jest przecież dalece odmienny od obrazu, który podsuwają nam intuicyjne wyobrażenia, znajdujące wyraz m.in. w dawnym imaginarium. Często jest również inny, niż wskazują na to nasze zmysły, jak w przypadku Słońca, które wydaje się kręcić wokół Ziemi. Skoro tyle razy pozwoliliśmy się zwodzić, to czy nie byłoby uzasadnione wattpić o naszych zdolnościach do poznania prawdy? Hannah Arendt pisała, że wątpienie pełni w nowożytnym myśleniu taką samą kluczową rolę, jaką w greckiej filozofii antyku pełniło thaumazein - dziwienie się wszystkiemu, co jest, że jest (2010: 308).

Jeszcze bardziej beznadziejne wydają się próby uchwycenia prawdy w dziedzinie moralności. Jeśli wszyscy jesteśmy tak dalece uwarunkowani, jeżeli często nie rozpoznajemy nawet dobrze przyczyn własnych działań, to jak możemy oceniać pod kątem etycznym czyjekolwiek postępowanie? Do jakich narzędzi się uciec? Odpowiedzią na te wątpliwości może być odrzucenie kategorii dobra i zła, czyli moralny relatywizm, choć jest to właściwie nie tyle odpowiedź, ile kapitulacja, uznanie swojej całkowitej bezradności. Jeśli odrzuci się pojęcie zła, każdy czyn może zostać usprawiedliwiony. Wiąże się z tym dekonstrukcja pojęcia natury ludzkiej w jego chrześcijańskim rozumieniu, opartym na kategorii grzechu pierworodnego. Słynna koncepcja „szlachetnego dzikusa” skażonego przez ciemiężycielską cywilizację, rozwijana przez tak wpływowych myślicieli jak Jean Jacques Rousseau (1956), stanowiła jakby pierwszy krok. Elity intelektualne Zachodu stopniowo przenosiły ciężar odpowiedzialności za ludzkie zło na czynniki zewnętrzne, przede wszystkim na źle urządzone społeczeństwo lub państwo, rozgrzeszając przy tym pojedynczego człowieka. Ostatnim 
etapem tego rozumowania jest całkowite odrzucenie pojęcia natury ludzkiej i uznanie człowieka za byt doskonale uwarunkowany - pogląd, o którym już wspominałem. Jak można byłoby uznać tak ubezwłasnowolniona istotę za winną czemukolwiek? O tym, jak dalece podobne wyobrażenie jednostki zagnieździło się w naszym potocznym myśleniu, pisał Leszek Kołakowski:

Jeśli wyobrażam sobie, że grzeszę, muszę po prostu pójść do psychoanalityka, a on mnie wyleczy z urojeń. [...] Wyobrażenie, że zło jest we mnie, w tobie, w nim, w niej, jest godne pogardy i infantylne. Pomyślmy jak ludzie poważni: jesteśmy - każdy z nas - ofiarami tego monstrum, tego ,społeczeństwa”, i nikt z nas w żaden sposób nie przyczynia się osobiście do tego, co to monstrum wyczynia. Wyznajmy to: taka jest nasza codzienna filozofia, filozofia całkowitej niewinności jednostki, odrzucenie osobistej odpowiedzialności, zanegowanie zła i grzechu, a ostatecznie zanegowanie człowieka [...] (Kołakowski 2014: 28-29).

\section{/// Złamać bramy Ulro}

Po opisie „naukowego światopoglądu” oraz jego wpływu na potoczne wyobrażenia o kosmosie i człowieku należałoby powrócić do wyjściowego pytania - czy w tym zmienionym, nieprzychylnym religijnym wierzeniom imaginarium chrześcijanin może ustrzec się herezji? Zdaniem Miłosza konflikt między wymogami religijnej wiary i ,naukowym światopoglądem” był nieunikniony. Nadziei dla chrześcijan upatrywał on jednak gdzie indziej. By w pełni zrozumieć jego perspektywę, warto wyjaśnić, czym jest kraina Ulro, do której przyrównywał współczesny świat naszych wyobrażeń. W poezji i malarstwie Williama Blake'a pojawiają się cztery symboliczne postaci, cztery pierwiastki natury ludzkiej, tworzące w człowieku rodzinę, której skłócenie doprowadziło do Upadku. Tharmas odpowiada ciału i jego potrzebom, Urthona wyobraźni, Luvah uczuciom i namiętnościom, Urizen zaś rozumowi. Ulro jest królestwem zrodzonym z pychy tego ostatniego, zbuntowanego Urizena, boga deistów, Wielkiego Zegarmistrza, budowniczego wszechświata, strażnika nienaruszalnych praw nauki, bóstwa redukcji, uogólnienia i statystyki (Miłosz 1982: 48, 174-181).

Ulro to piekło na ziemi, kraina duchowych męczarni, w której tkwili współcześni Blake’owi uczeni i w której za sprawą ekspansji ,naukowego 
światopoglądu" - zdaniem Miłosza - jesteśmy dziś uwięzieni niemal wszyscy. Przewodnikiem w podróży powrotnej do stanu zjednoczenia ludzkiej natury, do wyjścia z Ulro, może być tylko Urthona, twórcza wyobraźnia, moc odkupiająca, czerpiąca swą siłę z natchnień Ducha Świętego. Świat „naiwnych”, intuicyjnych wyobrażeń kształtowanych przez Urthonę wyzwala człowieka spod jarzma Ulro, zaspokaja jego duchowe potrzeby i dlatego może się stać niebem na ziemi (tamże: 181-182). Należy przy tym wyraźnie podkreślić, że sam Czesław Miłosz, zdeklarowany antyromantyk, nie nawoływał wcale do odrzucenia nauki i rozumu w imię powrotu do wyidealizowanej rzeczywistości sprzed narodzin nowożytnej nauki. Jego stanowisko było bardziej złożone. Pisał raczej o czymś, co za Taylorem nazwalibyśmy przemianą kosmicznego imaginarium: „Wyobraźnia wskazuje, gdzie może być ratunek: nie w oskarżaniu nauki, rzekomo odpowiedzialnej za wielkie nicestwienie, ale $\mathrm{w}$ zupełnie innym obrazie człowieka i świata niż ten, jaki ofiarowuje nam nauka osiemnastowieczna i jej pochodne po dziś dzień [...]" (tamże: 145).

Ziemia Ulro nie jest więc także jałowym esejem-skargą, stwierdzającym jedynie opłakaną kondycję ludzkiej egzystencji i podobnym w wymowie do dramatów Samuela Becketta. Jego autorowi przyświecał wyraźny cel, wykraczający poza pesymistyczną diagnozę, i choć swoje możliwości oceniał jako skromne, to sam cel skromny nie był - Miłosz chciał przyczynić się do „złamania bram Ulro” (tamże: 196). W jaki sposób? Jako poeta starał się ukazać czytelnikom granice ich wyobraźni, które czynią ich nieszczęśliwymi, klatkę zimnych praw dzisiejszej nauki więżących Urthonę. Przy tym zdawał sobie jasno sprawę - inaczej niż Goethe, który wykroczył poza domenę poety i usiłował obalić teorię Newtona na gruncie naukowym (tamże: 109-110) - że nie do niego należy wielkie zadanie jej uwolnienia. Tego dzieła mogą podjąć się obecnie już tylko naukowcy, naukowi heretycy, których wyobraźnia będzie zdolna przebić się przez wysokie mury przyjętych paradygmatów, a język zdoła oddać to, co za nimi ujrzeli - choćby były to Schrödingerowskie „skrzydlate lwy”. Dlaczego tylko oni? Ponieważ to ich - nie poetów i nie proroków - ekspansja „naukowego światopoglądu” uczyniła władcami naszej wyobraźni. 
Bibliografia:

/// Arendt H. 2010. Kondycja ludrka, tłum. A. Lagodzka, Wydawnictwo Aletheia.

/// Arendt H. 2011. Podbój kosmosu a ranga człtowieka, [w:] tejże, Między czasem minionym a przyszłym, tłum. M. Godyń, W. Madej, Wydawnictwo Aletheia, s. 317-335.

/// Arystoteles. 1968. Fizyka, tłum. K. Leśniak, Państwowe Wydawnictwo Naukowe.

/// Comte A. 2006. Rozprawa o duchu filozofii pozytywnej, tlum. W. Wojciechowska, [w:] Klasyczne teorie socjologiczne. Wybór tekstów, red. P. Śpiewak, Wydawnictwo Naukowe PWN, s. 3-27.

/// Durkheim É. 2011. Samobójstwo. Studium z socjologii, tłum. K. Wakar, Oficyna Naukowa.

/// Eliade M. 2008. Sacrum a profanum. O istocie sfery religijnej, tłum. B. Baran, Wydawnictwo Aletheia.

/// Hawking S. 1990. Krótka historia czasu. Od wielkiego mybuchu do czarnych driur, tłum. P. Amsterdamski, Wydawnictwo ALFA.

/// Heller M., Krajewski S. 2014. Czy fizyka i matematyka to nauki bumanistyczne?, Copernicus Center Press.

/// Husserl E. 1993. Kryzys europejskiego cztowieczeństwa a filozofia, tłum. J. Sidorek, Wydawnictwo Aletheia.

/// Kołakowski L. 1966. Filozofia pozytywistyczna (od Hume'a do Koła Wiedeńskiego), Państwowe Wydawnictwo Naukowe.

/// Kołakowski L. 1988. Jeśli Boga nie ma. O Bogu, diable, grzechu i innych żmartwieniach tak zwanej filozofii religii, Wydawnictwo Znak.

/// Kołakowski L. 2014. Jezus ośmieszony. Esej apologetyczny i sceptyczny, tłum. D. Zańko, Wydawnictwo Znak.

/// Miłosz Cz. 1982. Ziemia Ulro, Państwowy Instytut Wydawniczy.

/// Pismo Święte Starego i Nowego Testamentu. 1990. Wydawnictwo Pallottinum.

/// Rossi P. 1984. The Dark Abyss of Time, tłum. L. Cochrane, University of Chicago Press. 
/// Rousseau J.J. 1956. Rozprawa o podstawach i pochodzeniu nierówności między ludźmi, [w:] tegoż, Trzy rozprawy z filozofii spolecznej, tłum. H. Elzenberg, Państwowe Wydawnictwo Naukowe, s. 127-276.

/// Schrödinger E. 1952. Science and Humanism. Physics in Our Time, Cambridge University Press.

/// Strauss L. 2006. Reason and Revelation, [w:] Leo Strauss and the Theologico-Political Problem, red. H. Meier, Cambridge University Press, s. 141-180.

/// Tatarkiewicz W. 2003. Historia filozofii. Filozofia starożytna i średniowieczna, Wydawnictwo Naukowe PWN.

/// Taylor Ch. 2007. A Secular Age, The Belknap Press of Harvard University Press.

/// Watson J.B. 1990. Behawioryzm oraz Psychologia, jak widzi ja behawiorysta, tłum. E. Klimas-Kuchtowa, J. Siuta, Państwowe Wydawnictwo Naukowe.

/// Weber M. 1998. Nauka jako zawód i powołanie, tłum. P. Dybel, [w:] tegoż, Polityka jako zawód i powołanie, Wydawnictwo Znak, s. 111-140.

/// Weber M. 2006. Obiektywność poznania w naukach społecznych, tłum. M. Skwieciński, [w: Klasycæne teorie socjologicæne. Wybór tekstóm, red. P. Śpiewak, Wydawnictwo Naukowe PWN, s. 124-164.

/// Weber M. 2011. Racjonalność, władz̨a, odczarowanie, tłum. M. Holona, Wydawnictwo Poznańskie.

\section{/// Abstrakt}

Artykuł porusza zagadnienie wpływu spopularyzowanych ustaleń nauk ścisłych na funkcjonujące w obrębie cywilizacji zachodniej wyobrażenia o kosmosie i o człowieku przed nowożytną rewolucją naukową kształtowane w przeważającej mierze przez religię chrześcijańską. Autor omawia najpierw zaczerpnięte z Ziemi Ulro Czesława Miłosza pojęcie „światopoglądu naukowego", opisujące potoczny sposób postrzegania rzeczywistości, opierający się na daleko posuniętym zaufaniu do możliwości wyjaśniających nauki i powiązany z Weberowskim pojęciem „odczarowania świata”. Następnie przedstawia zarys historyczny procesu rozchodzenia się wizji rzeczywistości ukształtowanej na łonie religii chrześcijańskiej z prawdami nowożytnych nauk przyrodniczych, a także opisuje najbardziej fundamentalne z przemian zbiorowych wyobrażeń o kosmosie, do jakich to rozejście 
doprowadziło. Na koniec autor omawia wpływ, jaki powyższe przemiany wywarły na wyobrażenie człowieka o sobie samym, odwołując się m.in. do twórczości Samuela Becketta i Williama Blake’a.

Słowa kluczowe:

światopogląd naukowy, imaginarium kosmiczne, Ziemia Ulro, Czesław Miłosz, William Blake

\section{/// Abstract}

In the Land of U1ro: The Religious Vision of the Cosmos and the Human Being versus the Scientific Image of the World

This article discusses the influence of popularised findings of the natural sciences on Western images of the cosmos and the human being, which before the modern scientific revolution were shaped mostly by the Christian religion. The author first analyses the notion of a "scientific worldview" in Czesław Miłosz's The Land of Ulro, which describes a common way of perceiving reality that is based on a profound trust in the explanatory capacity of science and is linked to the Weberian notion of the "disenchantment of the world." The author then presents a historical outline of the growing distance between the vision of reality shaped by Christian religion and the truths of the modern natural sciences; he describes the most fundamental changes in the vision of the cosmos caused by this separation. Finally, he discusses the influence of these changes on the human being's image of himself, referring, inter alia, to the work of Samuel Beckett and William Blake.

Keywords:

scientific worldview, cosmic imaginary, The Land of Ulro, Czesław Miłosz, William Blake

/// Jonathan Scovil - doktorant na Wydziale Socjologii Uniwersytetu Warszawskiego oraz w École des Hautes Études en Sciences Sociales w Paryżu. Zajmuje się socjologia religii, historią idei oraz socjologią wiedzy. Publikował w „Studiach Socjologiczno-Politycznych”, „Kulturze i Wartościach” czy „Świecie Idei”. Stypendysta rządu francuskiego, a także laureat nagrody im. Floriana Znanieckiego II stopnia.

ORCID: https://orcid.org/0000-0002-7907-1447

E-mail: j.scovil@is.uw.edu.pl 